\title{
Etiological study of microcytic hypochromic anemia
}

\author{
Kafle $\mathrm{S}^{1}$, Lakhey $\mathrm{M}^{2}$ \\ ${ }^{I}$ Department of Pathology, Nepal Medical College Teaching Hospital, Kathmandu, Nepal. \\ ${ }^{2}$ Department of Pathology, Kathmandu Medical College Teaching Hospital, Kathmandu, Nepal.
}

\section{Keywords: \\ Microcytic; Hypochromic; Anemia; Iron; Thalassemia; Iron profile; Electrophoresis} \begin{abstract}
Background: Microcytic hypochromic anemia is a distinct morphologic subtype of anemia with welldefined etiology and treatment. The objective of this study was to determine the etiology and frequency of microcytic hypochromic anemia.
\end{abstract}

Materials and Methods: This cross-sectional observational study was conducted at Kathmandu Medical College Teaching Hospital. One hundred cases of microcytic hypochromic anemia were included. Relevant clinical history, hemogram, reticulocyte count, iron profiles were documented in a proforma. Bone marrow aspiration and hemoglobin electrophoresis was conducted when required. Data was analysed by Microsoft SPSS 16 windows.

Result: Iron deficiency was the commonest etiology (49\%). Dysfunctional uterine bleeding (20.8\%) was the commonest cause of iron deficiency, malignancy $(24.3 \%)$ was the commonest cause of anemia of chronic disease. Mean value of Mean Corpuscular Volume was lowest in hemolytic anemia (71.0fl). Mean Red cell Distribution Width was normal (14.0\%) in hemolytic anemia but was raised in other types. Mean serum iron was reduced in iron deficiency anemia $(32.2 \mu \mathrm{g} / \mathrm{dl})$ and chronic disease $(34.8 \mu \mathrm{g} / \mathrm{dl})$, normal in hemolytic anemia $(83 \mu \mathrm{g} / \mathrm{dl})$ and raised in sideroblastic anemia $(295 \mu \mathrm{g} / \mathrm{dl})$. Mean serum ferritin was reduced in iron deficiency anemia $(7.6 \mathrm{ng} / \mathrm{ml})$, raised in chronic disease $(158.6 \mathrm{ng} / \mathrm{ml})$ and normal in hemolytic anemia $(99.2 \mathrm{ng} / \mathrm{ml})$. Serum ferritin was normal in sideroblastic anemia $(93 \mathrm{ng} / \mathrm{ml})$. Mean Total Iron Binding Capacity was raised in iron deficiency anemia $(458 \mu \mathrm{g} / \mathrm{dl})$ and normal in other microcytic hypochromic anemias.

Conclusion: Diagnosis of microcytic hypochromic anemia requires a standardized approach which includes clinical details, hemogram, peripheral blood smear, reticulocyte count, iron profile, hemoglobin electrophoresis and bone marrow examination.

\section{INTRODUCTION}

Anemia is the most common disorder of blood. It is defined as a reduction below normal limits of the total

\footnotetext{
Correspondence:

Dr Sonali Kafle, MBBS, MD

Lecturer, Department of Pathology

Nepal Medical College Teaching Hospital,

Kathmandu, Nepal

Email: sonali.kafle14@gmail.com
}

circulating red cell mass or a reduction in the hemoglobin $\mathrm{Hb}$ ) concentration of the blood in comparison with the normal values for that age and sex. ${ }^{1}$ In Nepal, anemia is a well-known public health problem. High prevalence of anemia has been observed among teenagers, farmers, women and people belonging to the ethnic groups Lama, Sherpa and Tamang. ${ }^{2}$ International center for research has recorded high rates of anemia in Asia and Africa with $42 \%$ prevalence in Nepal, 55\% in India and 32\% in Cameroon. ${ }^{3}$ 
The morphologic approach which groups anemia by red blood cell (RBC) size into microcytic if the cells are smaller than normal, normocytic if they are of normal size ( $92 \pm 9 \mathrm{fl})$ and macrocytic if they are larger than normal. ${ }^{4,5}$ Microcytic hypochromic anemia can be classified into Iron Deficiency Anemia (IDA), Anemia of Chronic Disorders (ACD), disorders of globin synthesis Thalassemia, disorders of porphyrin and heme synthesis Sideroblastic Anemia (SA). 6,7

Iron replacement therapy is started in many centers without investigating patients to determine the cause. It is important to follow an orderly approach in microcytic hypochromic anemia so as to correctly diagnose the etiology. Prompt relief and significant improvement in patient condition can be made if the underlying etiology is recognized. On the contrary inappropriate therapy may be deleterious to the patient. Anemia due to chronic disease requires addressing the underlying cause and is not benefited by iron supplements. Iron overload is a known complication in undiagnosed thalassemia patients who are erroneously given iron therapy. Similarly reversible sideroblastic anemia due to acquired causes is treatable and requires removal of the inducing agent. Also, genetic assessment and different management is needed in suspected hereditary sideroblastic anemia. This study was intended to find the etiology of microcytic hypochromic anemia.

\section{MATERIALS AND METHODS}

This was a cross-sectional observational hospital based study conducted at Kathmandu Medical College Teaching Hospital, Pathology Department, from January 2012 to December 2012. Permission was obtained from institutional review committee. One hundred microcytic hypochromic anemias on peripheral blood film (PBF) were included. Clinical history, hemogram, reticulocyte count, iron profile was documented in a proforma. Bone marrow aspiration and hemoglobin electrophoresis was conducted when required. $5 \mathrm{ml}$ venous blood sample was collected in ethylene diamine tetraacetic acid vacutainer. Another $5 \mathrm{ml}$ blood was collected in a plain tube for iron profile. Wright's stain was done to examine peripheral blood films. Complete hemogram was performed in an automated hematology analyzer (Sysmex/Nihon Kohden). Colorimetry method with colorimeter (ELICO) was used to measure serum iron, Total Iron Binding Capacity (TIBC), Transferrin percentage saturation. Enzyme immunosorbent assay reader (STAT FAX 3300) was performed for quantitative serum ferritin. Hemoglobin Electrophoresis was performed by cellulose acetate method in electrophoresis tank at alkaline ph 8.6 after preparation of hemolysate. All data collected from proforma was entered in database created in Microsoft excel. The data set was then exported to Microsoft SPSS 16 version of windows for analysis. Frequency, percentage, mean and standard deviation of all the parameters were calculated.
Table 1: Etiology and its frequency in Iron defeciency anemia

\begin{tabular}{lc}
\hline \multicolumn{1}{c}{ Causes of IDA } & $\begin{array}{c}\text { Number of case } \\
(\%)\end{array}$ \\
\hline DUB & $10(20.4)$ \\
\hline Pregnancy & $9(18.3)$ \\
\hline Perimenopausal bleeding & $8(16.3)$ \\
\hline Chronic kidney disease & $6(12.2)$ \\
\hline Post major gastrointestinal surgery & $4(8.1)$ \\
\hline Leiomyoma & $\mathbf{3 ( 6 . 1 )}$ \\
\hline Hookworm & $\mathbf{3 ( 6 . 1 )}$ \\
\hline Gastric ulcer & $\mathbf{3 ( 6 . 1 )}$ \\
\hline Endometrial polyp & $\mathbf{2 ( 4 )}$ \\
\hline Endometriosis & $\mathbf{1 ( 2 )}$ \\
Total & $\mathbf{4 9 ( 1 0 0 )}$ \\
\hline
\end{tabular}

Table 2: Frequency of causes of anemia of chronic diseases

\begin{tabular}{|lc}
\hline \multicolumn{1}{|c}{ Causes of anemia of chronic diseases } & $\begin{array}{c}\text { Number of cases } \\
(\%)\end{array}$ \\
\hline Tuberculosis & $9(21.9)$ \\
\hline Diabetes Mellitus & $7(17.0)$ \\
\hline Ulcerative colitis & $5(12.1)$ \\
\hline Multiple Myeloma & $3(7.3)$ \\
\hline Idiopathic thrombocytopenic purpura & $2(4.8)$ \\
\hline Acute myeloid leukemia & $\mathbf{2 ( 4 . 8 )}$ \\
\hline Rectal polyp & $\mathbf{2 ( 4 . 8 )}$ \\
\hline Rheumatoid arthritis & $\mathbf{2 ( 4 . 8 )}$ \\
\hline Non Hodgkin lymphoma & $\mathbf{2 ( 4 . 8 )}$ \\
\hline Perianal fistula & $\mathbf{1 ( 2 . 4 )}$ \\
\hline Pancreatic carcinoma with & metastasis \\
\hline Lung cancer & $\mathbf{1 ( 2 . 4 )}$ \\
\hline Crohn's disease & $\mathbf{1 ( 2 . 4 )}$ \\
\hline Chronic osteomyelitis & $\mathbf{1 ( 2 . 4 )}$ \\
\hline Adrenal carcinoma & $\mathbf{1 ( 2 . 4 )}$ \\
\hline Systemic lupus erythematosus & $\mathbf{1 ( 2 . 4 )}$ \\
\hline Total & $\mathbf{1 ( 2 . 4 )}$ \\
\hline
\end{tabular}

\section{RESULTS}

Of 100 peripheral smears of patients with microcytic hypochromic anemia (fig. 1), 49\% were due to IDA and $41 \%$ were anemia of chronic disease. Hemolytic anemia including sickle cell anemia (fig. 2) accounted for 5\% cases. Sideroblastic anemia (fig.3) was seen in $1 \%$ and in $4 \%$ the cause could not be determined. Etiology of IDA is shown in Table 1. Dysfunctional uterine bleeding (DUB) was the commonest cause of iron deficiency (20.8\%). Commonest cause of microcytic anemia due to chronic disease was malignancy (24.3\%). Table 2.

Mean value of Mean Corpuscular Volume (MCV) was lowest in IDA (70fl). Mean value of Red cell Distribution Width (RDW) was highest in IDA (16.4\%) while it was normal in hemolytic anemia $(14.0 \%)$ which is shown inTable 3. 
Table 3: Mean values of $\mathrm{Hb}$ and $\mathrm{RBC}$ indices

\begin{tabular}{lccl}
\hline \multicolumn{1}{c}{ Type } & $\begin{array}{c}\text { Hb (g/d) } \\
(\text { Mean + S.D) }\end{array}$ & $\begin{array}{c}\text { MCV (fl) } \\
\text { (Mean + S.D) }\end{array}$ & $\begin{array}{l}\text { RDW (\%) } \\
\text { (Mean + S.D) }\end{array}$ \\
\hline ACD & $9.41+1.76$ & $82.8684+5.07762$ & $16.0659+1.10009$ \\
IDA & $9.89+1.20$ & $78.4090+4.150$ & $16.4605+2.13206$ \\
Hemolytic anemia & $9.22+1.32$ & $71.0+7.6$ & $14.0000+1.78885$ \\
Sideroblastic anemia & 9 & 82 & 18
\end{tabular}

Table 4: Mean values of Iron profile

\begin{tabular}{lclll}
\multicolumn{1}{c}{ Type } & $\begin{array}{c}\text { Iron }(\boldsymbol{\mu} / \mathbf{d l}) \\
\text { Mean+SD }\end{array}$ & $\begin{array}{l}\text { Ferritin(ng/mI) } \\
\text { Mean+SD }\end{array}$ & $\begin{array}{l}\text { TIBC( } \boldsymbol{\mu g} / \mathbf{d l}) \\
\text { Mean+SD }\end{array}$ & $\begin{array}{l}\text { Transferrin }(\% \text { saturation) } \\
\text { Mean+SD }\end{array}$ \\
\hline ACD & $34.8157+17.92862$ & $158.6052+30.64521$ & $304.5455+16.40399$ & $13.4236+6.27458$ \\
IDA & $32.2895+13.23980$ & $7.6311+3.90272$ & $458.3158+74.36873$ & $6.1068+3.72683$ \\
Hemolytic anemia & $83.2000+12.43785$ & $99.2000+23.20991$ & $301.8000+19.16246$ & $27.6000+4.43396$ \\
Sideroblastic anemia & 295.0000 & 93.0000 & 163.0000 & 180.0000
\end{tabular}

\section{Table 5: Hb electrophoresis findings}

\begin{tabular}{lcc}
\hline \multicolumn{1}{c}{ Types of band } & Diagnosis & Number of cases \\
\hline $\mathbf{H b A}+\mathbf{H b F}$ & Beta thalassemia Major & 1 \\
$\mathbf{H b A}+\mathbf{H b A 2}+\mathbf{H b F}$ & Beta thalassemia Trait & 3 \\
$\mathbf{H b S}+\mathbf{H b A}$ & Sickle Cell trait & 1
\end{tabular}

Mean value of serum iron was reduced in IDA $(32.2 \mu \mathrm{g} / \mathrm{dl})$ and $\mathrm{ACD}(34.8 \mu \mathrm{g} / \mathrm{dl})$. It was normal in hemolytic anemia $(83 \mu \mathrm{g} / \mathrm{dl})$ and was raised in SA $(295 \mu \mathrm{g} / \mathrm{dl})$. Mean serum ferritin was reduced in IDA $(7.6 \mathrm{ng} / \mathrm{ml})$, raised in ACD $(158.6 \mathrm{ng} / \mathrm{ml})$ and normal in hemolytic anemia $(99.2 \mathrm{ng} / \mathrm{ml})$. Serum ferritin was normal in SA $(93 \mathrm{ng} / \mathrm{ml})$. The mean TIBC was raised in IDA $(458 \mu \mathrm{g} / \mathrm{dl})$ and normal in other causes of microcytic hypochromic anemia. Table 4 . Five out of the nine patients on whom electrophoresis was done showed abnormal $\mathrm{Hb}$ bands. Three were cases of $\beta$ thalassemia trait (fig.4), one was a case of $\beta$ thalassemia major and one patient was diagnosed as sickle cell trait. (Table 5)

\section{DISCUSSION}

Microcytic hypochromic anemia is a distinct morphological subgroup characterized by significant reduction in red cell size combined with increased central pallor of the red cells. The etiology is well defined and an orderly approach has been established in arriving at a definite diagnosis. Similar to this study, in most series iron deficiency anemia and thalassemia trait were the commonest causes of a microcytic hypochromic blood picture. ${ }^{8}$ Mach-Pascual $\mathrm{S}$ and colleagues found iron deficiency anemia to be the leading cause of microcytosis $(45.2 \%))^{9}$ Sinha, et al found a high incidence of IDA (40.57\%) among 262 people presenting with microcytic hypochromic anemia on peripheral blood smear.10 DUB resulting in blood loss was the commonest cause of IDA in this study. A study of Swedish women showed that despite a dietary intake of about $10 \mathrm{mg}$ of iron per day, $67 \%$ of women with menstrual

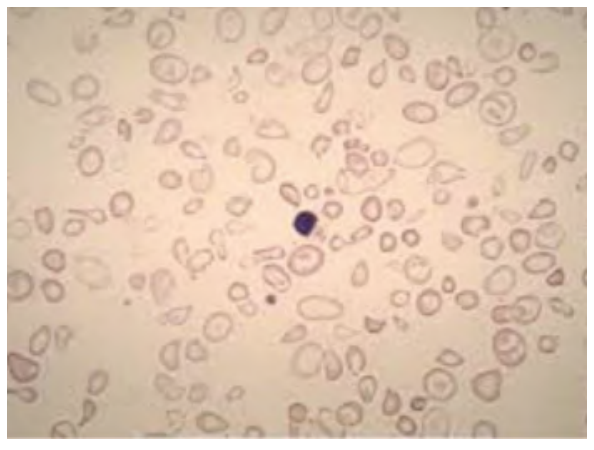

Figure 1: Photomicrograph showing microcytic hypochromic anemia with marked anisopoikilocytosis.(Wright's stain,X100).

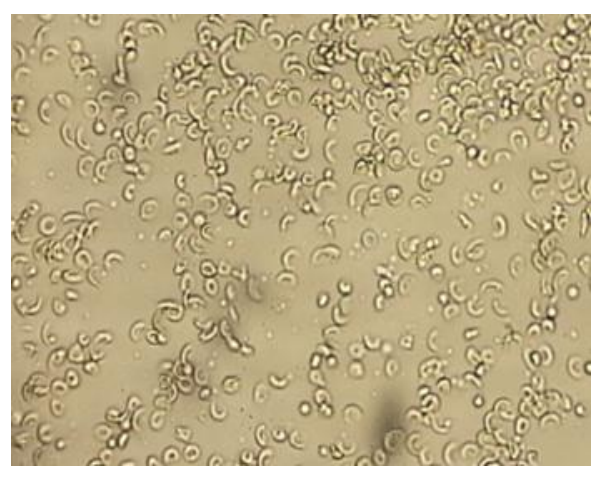

Figure 2: Photomicrograph showing positive sickling test (Unstained film,X100).

blood loss exceeding $80 \mathrm{ml} /$ period were anemic. ${ }^{11}$ Anemia of chronic disease is the second most prevalent cause of anemia after iron deficiency anemia. Peripheral blood film in ACD is usually normocytic normocytic. Advanced disease causes microcytic hypochromic appearance of red cells. It is commonly associated with chronic infectious, inflammatory or neoplastic disorders and is characterized by hypoferremia. Anemia of chronic disease does not include anemia caused by renal or hepatic insufficiency. ${ }^{12}$ Recent observations have however shown that apart from 


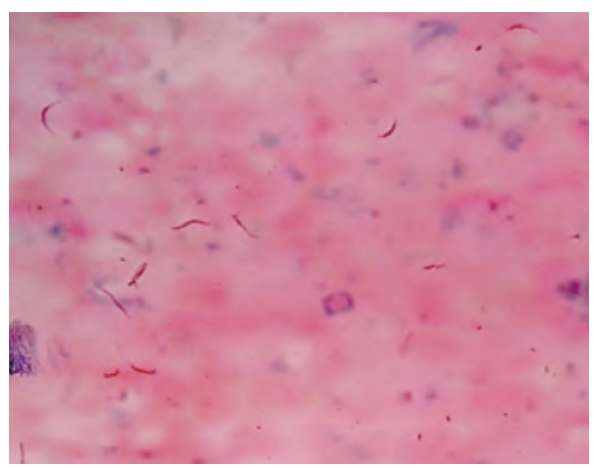

Figure 3: Photomicrograph of ringed sideroblasts (Perl's Prussian blue stain,X100).

infections, inflammation and malignancy, ACD can be seen in a variety of conditions including severe trauma, diabetes mellitus and anemia of the elderly. ${ }^{13}$ Anemia of chronic disease remains under recognized and undertreated. ${ }^{14}$

The diagnosis of pure IDA or ACD is straight forward In some situations however, conventional laboratory tests for iron status are influenced by the inflammatory response and their diagnostic accuracy may be undermined. New tests are available but grey zones and diagnostic uncertainties sometimes remain. ${ }^{15}$ In this study the exact cause of anemia could not be detected in 4 percent. The serum iron and TIBC in these patients was normal, ferritin reduced. Mean Transferrin percentage saturation was low (13\%). The transferrin saturation falls below normal, often less than $15 \%$ in both IDA and ACD but values below 5\% are seen only in IDA. Therefore due to values of normal serum iron and TIBC, transferrin percentage value between $12 \%$ and $15 \%$, definite IDA could not be established in these patients. From the information provided above it may be inferred that fluctuations in the levels of serum iron profile may arise in many cases and that no single biochemical parameter can by itself segregate IDA from other causes of non IDA microcytic anemia. When values of iron profile other than those expected in IDA and ACD are retrieved in the absence of clinical disease or active bleeding, it may be difficult to point out the exact cause of anemia. Combined approach including the clinical scenario and biochemical parameters may be helpful in such cases.

Hemolytic anemia was suspected in 5 cases on peripheral smear. Morphology of thalassemia trait and iron deficiency anemia is similar on peripheral smear. Hb electrophoresis is mandatory in distinguishing the two. The principal limitation of $\mathrm{Hb}$ electrophoresis is that it may miss thalassemia traits with low percentage of $\mathrm{HbF}$ and $\mathrm{HbA} 2$. This can be overcome by use of High Performance Liquid Chromatography (HPLC) which quantifies levels of $\mathrm{Hb}$ even below $5 \%$.

\section{CONCLUSION}

Microcytic hypochromic anemia has a diverse etiology. Microytic hypochromic anemia is detected with the help of

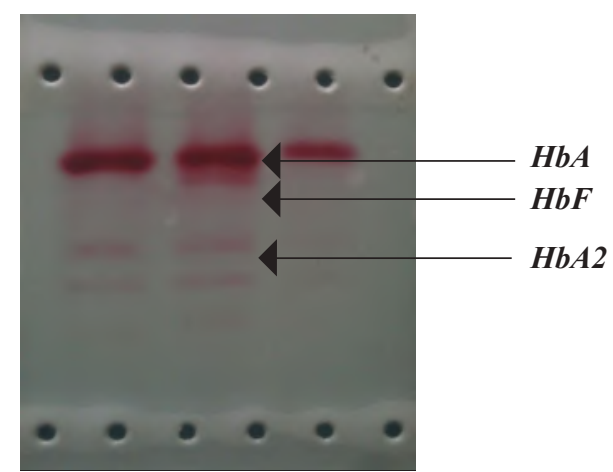

Figure 4: Photomicrograph of $\beta$ thalassemia trait in Hb electrophoresis cellulose.

hemogram and peripheral blood film. Serum iron profile, bone marrow iron stain and $\mathrm{Hb}$ electrophoresis are a must for confirmation of etiology.

\section{REFERENCES}

1. Aster JC. Red Blood Cell and Bleeding Disorders. In: Kumar V, Abbas AK, Favsto N. Robbins and Cotran Pathologic Basis of Disease. 7th ed. Noida, India: Elsevier; 2005. p. 622-3.

2. Bondevik GT, Lie RT, Ulstein M, Kvale G. Seasonal variation in risk of anemia among Nepali women. Int J Gynecol Obstet 2000;69:21522. Crossref

3. Kurz KM. The Nutrition and Lives of Adolescents in Developing Countries: Findings from the Nutrition of Adolescent Girls Research Program. Proc Nutr Soc 1996;55:321-31. Crossref

4. Beutler E, Lichtman MA, Coller BS. Williams hematology. 6th ed. New York: McGraw-Hill; 2000. p.371-2.

5. Hoffman R, Benz EJ Jr, Shattil SJ. Hematology basic principles and practice: approach to anemia in the adult and child. New York: Churchill Livingstone;1998.p.439-446. Crossref

6. Fraser JG. The Golden Bough: The magic art in the evolution of kings. New York: MacMillan; 1935.p.158.

7. Vanhove L, Schisano T, Brace L. Anemia diagnosis, classification, and monitoring Using Cell-Dyn Technology Reviewed for the New Millennium. Laboratory Hematology 2000;6:93-108.

8. Uprichard W. Investigating Microcytic anemia. BMJ 2013;346:f3154. Crossref

9. Mach-Pascual S, Darbellay R, Pilotto PA, Beris P. Investigation of microcytosis: A Comprehensive Approach. Er J Hematol 1996;51:5461. Crossref

10. Sinha AK, Majumdar B, Yadav SK. Prevalence and significance of Iron deficiency anemia among people of Morang district of Nepal. Journal of Nobel Medical College 2011;1:40-44.

11. Hallberg L, et al. Menstrual blood loss and iron deficiency. Acta Med Scand J Clin Lab Invest 1964;16:244. Crossref

12. Matzner Y, Levy S, Grossowicz N, Izak G, Hershko C. Prevalence and causes of anemia in elderly hospitalized patients. Gerontology 1979;25:113-9. Crossref

13. Price EA, Schrier SL. Unexplained aspects of anemia of inflammation. Adv Hematol 2010; 2010:508739.

14. Weiss G. Pathogenesis and treatment of anemia of chronic disease. Blood Rev 2002;16:87-96. Crossref

15. Celi J, Samii K, Perrier A, Reny JL. Iron deficient anemia, anemia of chronic disease or mixed anemia: how to determine the diagnosis? Rev Med Suisse 2011;7:2018-3. Crossref 